\title{
Iowa Jewish Heritage: An Annotated Bibliography
}

\author{
COMPILED BY \\ Karen G. Bell and Michael J. Bell
}

JEWS have lived in Iowa since the 1830s, but the Jewish community's history in the state took shape in three successive stages. Beginning in 1880 Iowa's Jewish population expanded from approximately one thousand to more than nine thousand at the end of open immigration in 1925. From 1926 to the $1940 \mathrm{~s}$ the population almost doubled again as Jews spread across the state to communities large and small and integrated themselves into the social, cultural, and economic life of the state. Finally, from the end of World War II to the present the Jewish population has shrunk to approximately 5,500 individuals. The following bibliography contains articles, selected newspaper reports, and books, with full citation and annotation, which deal wholly or in part with the history of that growth and development. It was prepared as a result of a grant from the Jewish Federation of Greater Des Moines to the State Historical Society of Iowa to begin a scholarly history of Jewish life and heritage in Iowa. It covers the known and available materials from the nineteenth and twentieth centuries.

Some of the materials cited are available in local Iowa libraries, but most must be obtained through interlibrary loan, computer search services, or direct contact with appropriate archives and museums. This is especially the case with the American Jewish Archives materials, which are located at He-

THE ANNALS OF IOWA 53 (Spring 1994). CThe State Historical Society of Iowa, 1994. 
brew Union College in Cincinnati, Ohio. As this bibliography demonstrates, their collection of Iowa materials is extensive.

In addition to the materials cited here, we have collected more than 150 oral histories, most of which have been transcribed. The tapes and transcripts are held at Grinnell College. We have also compiled an extensive bibliography of Iowa newspaper references to Jewish life in the state. We have not included those materials here because that work is still incomplete, and rather than present partial results, we have deferred its publication. Furthermore, most of the major references, most notably the Des Moines Register, are already indexed in the standard sources for Iowa's newspaper collections.

This bibliography is intended for scholars and othersJewish or not-who are interested in the contributions of this distinctive minority to the life and heritage of the state. Accordingly, we have been inclusive rather than exclusive in selecting and annotating materials. We selected materials based solely on the presence of reference to Iowa-related Jewish heritage regardless of the genre in which it appeared. Thus, we include materials from autobiographies and biographies that might not normally appear in scholarly bibliographies. For the same reasons, we have left critical commentary aside. Our annotations provide descriptions of the materials cited, but we do not editorialize on its worthiness or usefulness, believing that those decisions are best left to readers who know best the relevance of individual texts to their specific projects.

\section{BOOKS}

\section{Iowa}

Bonomi, Ferne G., and Robert F. Bonomi. Show Me a Man . . . Ellis I. Levitt. Des Moines: Penny Press, 1969.

Biography of Ellis I. Levitt, philanthropist, founder of Dial Finance Company. Among many accomplishments, Levitt is credited with conceiving the idea of having an All-in-One Campaign in Des Moines linking all fund appeals - local, national, and international - into one giving campaign. 
Connor, Susan Marks. I Remember When ... Personal Recollections and Vignettes of the Sioux City Jewish Community, 1869-1984. Sioux City: Jewish Federation of Sioux City, 1985.

Begun by the Sioux City Jewish Federation's historian and former executive director Oscar Littlefield as a sequel to Bernard Shuman's A History of the Sioux City Jewish Community, 1869-1969, this book was finished by Susan Marks Connor. It describes the "evolution and growth" of the community, mostly through personal recollections, putting the migration of Jews in the United States into historical perspective. Sources of information include interviews, unpublished diaries, letters, newspaper articles, etc. Many photographs are included. The Jewish community's annual homecoming picnic reunions are discussed.

Ferber, Edna. A Peculiar Treasure. New York: Doubleday, Doran \& Co., 1939.

Edna Ferber's autobiography contains her acerbic description of growing up in Ottumwa, Iowa (30-47): "Those next seven years - from 1890 to 1897 - must be held accountable for anything in me that is hostile toward the world in which I live. Child though I was, the brutality and ignorance of that little town penetrated to my consciousness, perhaps through casual talk as I heard it between my young parents; certainly as it was visited upon me" (31).

Fleishaker, Oscar. "The Illinois-Iowa Jewish Community on the Banks of the Mississippi River." Ph.D. dissertation, Harry Fischel School for Higher Jewish Studies, Yeshiva University, 1957. Published privately by the author, 1971 .

Fleishaker describes in rich detail the foundings and growth of the several Jewish communities bordering the Mississippi River, including those in Keokuk, Burlington, Davenport, Rock Island, and Dubuque, with many photographs. Included in appendixes are lists of congregation members, Jewish-owned businesses, towns with Jewish communities, as well as cemetery records, excerpted sisterhood minutes, etc.

Glazer, Simon. The Jews of Iowa. Des Moines: Koch Brothers Printing, 1904.

In this book, the earliest history of Iowa's Jewish communities, Rabbi Glazer provides detailed descriptions of the origins and development of the state's Jewish life and heritage, including histories of community life in Des Moines, Davenport, and Sioux 
City, the development of religious institutions in other communities, correspondence with earliest settlers, firsthand descriptions of major events, etc. The work is divided into three parts: a history of Iowa, including relevant details of early Jewish settlement; a history of the Jews since the Diaspora; and a detailed description of Iowa Jewish history from its territorial beginnings to 1904. Especially significant is the work's reliance on responses to circulars mailed to two thousand Jewish citizens of the state and on visits to each of the Jewish communities to obtain and verify information.

Harlan, Edgar Rubey. "The Jews." In A Narrative History of the People of Iowa. Vol. 2, pp. 469-73. 5 vols. Chicago and New York: American Historical Society, 1931.

An entry in the "Religion" section of this history of Iowa's settlers, this piece draws heavily on information obtained from Rabbi Simon Glazer's book, The Jews of Iowa. It describes the early communities, mentioning the names of prominent citizens and businesses, as well as their congregations. It briefly discusses Jewish participation in charitable, patriotic, and civic work during World War I.

Noun, Louise Rosenfield. Journey to Autonomy: A Memoir. Ames: Iowa State University Press, 1990.

Memoirs of Louise Rosenfield Noun, author, feminist, and political activist, covering her memories and the family histories of the Frankels, the Scheuermans, and the Rosenfields from the 1840 s to 1990 . This work is especially useful in providing a feminist political analysis of being both a woman and Jewish in Iowa. Especially relevant for their broad perspective on Iowa Jewish history are the chapters dealing with family, growing up, and education and travel, but every chapter makes a contribution to the discussion of the history of Iowa's Jewish women.

Petersen, William J. "The Jews in Iowa." In The Story of Iowa: The Progress of an American State. Vol. 2, pp. 745-48. 4 vols. New York: Lewis Historical Publishing Co., 1952.

This entry provides a brief history of Iowa Jewry beginning with a mention of Alexander Levi's arrival in Dubuque and ending with statistics from the U.S. Census Bureau's 1936 religious census in the state. It describes the origins of several Jewish communities. It lists the number of congregations as 26 , the total 
number of members as 11,888 , the number of "church edifices" as 24 , and the number of "Sunday school scholars" as 629 .

Postal, Bernard, and Lionel Koppman. American Jewish Landmarks: A Travel Guide and History. Vol. 3, The Middlewest, pp. 86-98. New York: Fleet Press Corp., 1976.

The American Jewish Landmarks series provides an overview of Jewish history in each state and lists significant historic events and sites in cities in the state, including the Jewish origin of one town name (Solberg, named for a peddler). For the traveler, it also notes the addresses of all synagogues. The brief essay on the history of Iowa's Jewish communities mentions citizens, dates, and events, and cites some "firsts" (oldest cemetery inscriptions, first communities established, earliest congregations, etc.). There are individual entries for Ames, Burlington, Cedar Rapids, Clinton, Council Bluffs, Davenport, Des Moines, Dubuque, Fort Dodge, Iowa City, Madrid, Marshalltown, Mason City, Muscatine, Ottumwa, Sioux City, Solberg, Waterloo, Webster City, and West Branch.

Rosenthal, Frank. The Jews of Des Moines: The First Century. Des Moines: Jewish Welfare Federation, 1957.

In this, the most recent history of the Des Moines Jewish community, Professor Frank Rosenthal, a Drake University historian, divides his narrative into six chapters dealing in turn with the earliest beginnings of the Des Moines community, its division into east side (predominantly Orthodox) and west side (predominantly Reform and Conservative) communities, the development of the various religious communities, the creation of community organizations, the history of Jewish charity, and the involvement of the Jewish community in wider Des Moines, Iowa, national, and international events. In part because of its reliance on Rabbi Eugene Mannheimer's diaries and notebooks, the work has a twentieth-century emphasis. It includes index, bibliography, and photographs.

Shuman, Bernard. A History of the Sioux City Jewish Community, 1869 to 1969. Sioux City: Jewish Federation, 1969.

A centennial history of the Sioux City Jewish community commissioned by the Jewish Federation. The work includes details of religious and community life from Godfrey Hattenbach's arrival in Sioux City in 1857 to the centennial year of 1969, with excellent descriptions of the Orthodox, Conservative, and Reform 
communities and the formation of philanthropic organizations and community educational institutions as well as a personal commentary by Oscar Littlefield (director of the Sioux City Jewish Federation), photographs, lists of donors, patrons, contributors, a directory of the Jewish community, references, and acknowledgments.

Wolfe, Jack Seymour. A Century with Iowa Jewry. Des Moines: Iowa Printing \& Supply, 1941.

This book details the origins of Jewish life in Iowa and tells of the founding of Iowa's Jewish communities. Part one covers the period from 1833 through the Civil War; part two focuses on Des Moines, telling of its pioneer families, early business leaders, the establishment of its synagogues and other community institutions, the role of women in the community, etc.; and part three provides short entries on Sioux City, the Tri-Cities, Cedar Rapids, Waterloo, Council Bluffs, Dubuque, Iowa City, Ottumwa, Mason City, Marshalltown, Fort Dodge, Oskaloosa, and "smaller Jewish communities," such as Centerville, Muscatine, and Keokuk. Photographs of some community leaders are included.

\section{General Reference}

Center for Applied Urban Research, University of Nebraska at Omaha. Demographic Survey of the Omaha Jewish Community. Omaha: Center for Applied Urban Research, 1976.

A basic demographic survey of the Omaha Jewish community designed as a planning document for the Omaha Jewish Federation in 1976. It provides data on such subjects as population characteristics, family status, socioeconomic condition, religious identity, and use of Federation services. Appendixes report on methodological considerations, the questionnaire format, computer coding, and lists of variables applied.

Guide to the United States for the Jewish Immigrant. English edition. Connecticut DAR, 1912.

One of a series of "how-to-become-American" guides published by the Daughters of the American Revolution, this book (a copy of which is in the Henry W. Grout Museum of History and Natural Science in Waterloo) gives instructions to immigrants on surviving the transition to American life. Includes information on American life and values as well as helpful hints on dealing with money, railroad timetables, etc. 
Horowitz, Harvey P., and Frank J. Adler. Roots in a Moving Stream: The Centennial History of Congregation B'nai Jehudah of Kansas City, 1870-1970. Kansas City: Congregation B'nai Jehudah, 1972.

A comprehensive history of Congregation B'nai Jehudah of Kansas City, the city's first Reform temple.

Libo, Kenneth, and Irving Howe. We Lived There Too. New York: St. Martin's/Marek, 1984.

A companion volume to Howe and Libo's World of Our Fathers, this documentary history of American Jews outside of New York City includes original documents, firsthand descriptions, and pictures of the Jewish participation in the settlement of the United States from the sixteenth to the twentieth centuries. Its sole Iowa contribution is Edna Ferber's uncomplimentary description of growing up in Ottumwa.

Plaut, W. Gunther. The Jews in Minnesota: The First Seventy-five Years. New York: American Jewish Historical Society, 1959.

A linear history of the growth and development of Jewish life and culture in Minnesota from the 1880s through 1959. Appendixes cover such topics as origins of congregations, population statistics, and military service and occupations of early residents. Includes a glossary, index, and references.

Rochlin, Harriet, and Fred Rochlin. Pioneer Jews: A New Life in the Far West. Boston: Houghton Mifflin, 1984.

This work describes in rich detail the history of Jewish settlement and involvement in the social, cultural, and economic life of the Far West. Its eight chapters deal with, among other subjects, the first settlers, the Gold Rush, early Jewish entrepreneurs, notable Jewish rogues, rascals, and characters of far western history, etc. Includes bibliography, index, and excellent photographs.

Schultz, Joseph P., ed., Mid-America's Promise: A Profile of Kansas City Jewry. Kansas City: Jewish Community Foundation of Greater Kansas City, 1982.

A collection of essays profiling Jewish life and culture in Kansas City from pioneer beginnings to the present. Individually authored articles explore such topics as religious life, education, philanthropy, resettlement, and community involvement in public government and civic activities. Includes a demographic profile based on three studies performed since 1962, bibliographies for each article, several photographs, and an index. 


\section{JOURNAL ARTICLES}

\section{Iowa}

"Church-State Issues." Christian Century 105 (12 October 1988), 889-90.

A short (1000-word) description of the American Jewish Congress's opposition to placing a menorah on Iowa statehouse grounds during the holiday of Hanukkah.

Druker, Rose, and Harry Druker. "The Jews of Marshalltown." Then and Now: Journal of the Historical Society of Marshall County 12 (September 1988), 1-4, 6 .

The Drukers, longtime community residents, trace the history of Marshalltown's Jewish community from the arrival of its first settlers in the 1860s. Provides information on the founding of a congregation, the religious and community leaders, and the relationship between community members and national organizations.

Dunlap, Flora. "Roadside Settlement of Des Moines." Annals of Iowa 21 (January 1938), 161-209.

A description of the founding and work of the Roadside Settlement of Des Moines, this article includes a description of the work of the Jewish Settlement of Des Moines.

Engle, Paul. "Those Damn Jews ..." American Heritage 30 (December 1978), 72-79.

A moving and sometimes poignant description of the "coming of age" in Cedar Rapids of the founder of the Iowa Writers Workshop and, particularly, of the deep and lasting effect that his youthful friendship with a local Jewish businessman had on his attitudes and his work.

Foster, Margaret. "Children of Israel Cemetery Tombstone Inscriptions." Hawkeye Heritage 18 (Summer 1983), 74-77.

A catalog of tombstone inscriptions for the eastside Jewish cemetery in Des Moines. The cemetery, misidentified as belonging to Children of Israel Congregation, is actually the property of Congregation Beth El Jacob.

Griff, Hanna. "Toldot Iowa Diary." Jewish Folklore and Ethnology 13 (1991), 13-19.

A reflexive article in which Griff talks about the first year of fieldwork on the Jews of Iowa Oral History project. She examines 
issues of ethnicity and fieldwork techniques and the ability of the fieldworkers to focus on individuals and their work, community, and family, as well as addressing the problem of having nonJewish students conduct the bulk of the fieldwork.

Hornstein, Frank. "The Farm Crisis: Jewish Community Response." Schmate 16 (Fall 1986), 22-25.

A discussion of the rise of rural anti-Semitism in response to the farm crisis of the early 1980s and the attempts by right-wing extremist groups to organize farmers in opposition to "Jewish international bankers," this report focuses on Jewish responses, including the efforts of the Anti-Defamation League, Woman's American Organization for Rehabilitation Training [ORT], PrairieFire, and others both to combat rural anti-Semitism and to increase dialogue between the rural and urban communities of the Middle West.

"Iowa's Mother of the Year." United Synagogue Review 17 (Spring 1964), 16-18.

Hilda Weingart, wife of Rabbi Irving A. Weingart of Tifereth Israel Synagogue in Des Moines, was chosen Iowa's Mother of the Year in 1964. This article tells of her accomplishments and participation in community activities. Includes photographs of Mrs. Weingart and her family.

Mann, Annette. "A History of the Jews of Des Moines." The Reform Advocate, 9 May 1908, 10-44.

An essay-length description of the Des Moines Jewish community published as a part of a special Iowa issue of the Reform Advocate. Includes descriptions of major institutions and individuals involved in community religious, philanthropic, and social life.

Nefzger, Den, and Peter Kivisto. "Studying the Changing Conditions of Jewish Life in a Middle-Sized American City." Sociological Focus 23 (1990), 177-201.

An essay-length study (based on survey data) of the QuadCities Jewish community, focusing on the ethnographic composition of the community, with particular attention to religious orientation, occupation, marital status, and educational attainment. 
Oransky, L. "Des Moines Section: Des Moines Jewry-A Record of Achievement." American Jewish World 13 (26 September 1924), $45-69$.

This special section, unbound and inserted in the center of the journal, includes photographs, local advertising, and brief articles on various aspects of community life by members of the Des Moines community, including "The United Jewish Philanthropies," by L. Oransky, President; "Mrs. Samuel Weinstock-An Interview," by A. I. Harris; "The Des Moines Talmud Torah," by Seppy I Silberman, President; "The Des Moines Hadassah Chapter," by Mrs. M. L. Kohn; "The Junior Hadassah," by Miss Jeanette Lutz; "Des Moines Lodge, Order B'nai B'rith," by J. S. Slate, President; "The Ideals of Reform Judaism," by Rabbi Eugene Mannheimer (B'nai Jeshurun); and "The Need of Adult Jewish Education," by Rabbi Solomon Rivlin (Tifereth Israel).

The Reform Advocate (Iowa Edition). 14 December 1912, 8 February 1913.

These two special editions of the national Reform Jewish publication, edited by Emil G. Hirsch, provide a look at life in Iowa's Jewish communities, with individual sections on Des Moines, Cedar Rapids, the Tri-Cities, and Sioux City. Intended in part to demonstrate the viability of midwestern Jewish life and highlight the successful assimilation of Reform Jews, the issues offer articles on prominent citizens and businesses, detailed descriptions of the religious communities, and information on Jewish and local civic institutions. Included are photographs of community leaders and their homes, synagogues, settlement houses, and local landmarks.

Schoenbaum, David. "The Truth Makes Us Free Though Not Especially Happy." Present Tense 11 (Spring 1984), 31-35.

A description of the author's experiences in teaching a history course, "Historical Background of the Arab-Israel Conflict," at the University of Iowa in the fall of 1983. Includes personal reflections by both the author and his students.

Smith, C. J. "Rural Radical Right: Politics of Fear and Hatred amidst the Farm Crisis." e/sa 131 (June 1987), 20-23.

A short, informative article on the Posse Comitatus and the racist Christian Identity movements in Iowa and the Midwest. Provides background and commentary on other similar movements. "Across the midwest, rural radical right organizers have 
built an infrastructure for a racist and anti-Semitic movement upon the despair and frustrations of the region's family farmers and the crisis in the rural communities around them."

"Trail Blazers of the Trans-Mississippi West." American Jewish Archives 8 (October 1956), 59-130.

This article discusses the westward movement of the earliest Jewish settlers, dealing only marginally $(80-81)$ with the early settlement of Iowa and the rise of Jewish peddlers in the state.

\section{General Reference}

Douglas, Donald M. "Forgotten Zions: Jewish Agricultural Colonies in Kansas in the 1880s," Kansas History 16 (Summer 1993), 108-19.

This essay details the rise and fall of the seven ZionsTouro, Lesser, Beersheba, Lasker, Montefiore, Gilead, and Hebron -founded in Kansas. It describes the economic and social organization of each: Beersheba as individually owned land farmed with sponsor-owned equipment; Montefiore and Lasker as utopian, communal Am Olam (Eternal People) colonies; Hebron and Gilead as partially subsidized farms; and Turo and Lesser as completely individual initiatives. Douglas concludes that these communities "exemplify, as perhaps nowhere else, all of the facets of Jewish agricultural effort in the nineteenth century."

Farber, Bernard. "Kinship Mapping among Jews in a Midwestern City." Social Forces 57 (June 1979), 1107-23.

Based on data obtained from the Jewish community of greater Kansas City, this essay explores the relative influence of communal and associational factors on kinship in an urban setting. Farber demonstrates that orthodoxy of religious upbringing predicts lineal emphasis mapping better than current religious activity. More importantly, he demonstrates that living in an area with a high concentration of Jews and disapproving of intermarriage are equally highly associated with kinship mapping.

Frost, Murray. "Analysis of a Jewish Community's Out-Migration." Jewish Social Studies 44 (Summer/Fall 1982), 231-38.

An analysis of a 1975 demographic survey of Midam (a pseudonym), a midwestern Jewish community of approximately 6,500, which demonstrates (1) an increasingly aged population, (2) a declining Jewish birth rate, (3) the postponement of marriage, (4) 
a rise in professionals and a decline in proprietors in the economic structure, and (5) an increasing rate of intermarriage. This analysis, which confirms the findings of other local demographic studies and the National Jewish Demographic Survey of 1974, concludes that increased mobility will likely increase observed trends.

Goering, Violet, and Orlando J. Goering. "Jewish Farmers in South Dakota - the Am Olam." South Dakota History 12 (Winter 1982), 232-47.

This essay focuses on two South Dakota farming settlements, Cremieux and Bethlehem Yehudah, established by the Am Olam (Eternal People) movement in the 1880 s. This movement had as its goal "to help the Jewish people in its emancipation from slavery and in its rehabilitation to a new truth, freedom, and peace. The colony [Bethlehem Yehudah] shall demonstrate to the enemies of our people the world over that Jews are capable of farming" (245).

Himmelfarb, Harold S. "Patterns of Assimilation-Identification among American Jews." Ethnicity 6 (1979), 249-67.

This essay explores the relationship between American Jews' assimilation to American culture and their self-identification as Jewish. It includes information from several unidentified Iowa cities.

Pollak, Oliver B. "The Jewish Peddlers of Omaha." Nebraska History 63 (Winter 1982), 474-501.

Based on membership lists of five peddler unions, this socioeconomic examination of midwestern and, particularly, Omaha peddlers, pays particular attention to the impact of peddlers on midwestern mercantile and consumer patterns. The essay concentrates almost exclusively on Omaha, but has some references to the relationship between Omaha traders and western Iowa.

Rosenswaike, Ira. "The Utilization of Census Mother Tongue Data in American Jewish Population Analysis." Jewish Social Studies 33 (April-June 1971), 141-59.

This essay argues that the census-based mother tongue classification represents "the most substantial tool we have available in analyzing the historic demographic trend within the American Jewish community over the course of the eventful half-century, 
1910 to $1960 "$ "141). Its appendix pays particular attention to the Iowa State Census of 1925 as a demonstration case for determining the relationship between Yiddish mother tongue statistics and Jewish population statistics.

Sarna, Jonathan D. "Jewish Community Histories: Recent NonAcademic Contributions." Journal of American Ethnic History 6 (Fall 1986), 62-70.

A review essay, this article describes several popular and local histories of Jewish communities, including Susan Marks Connor's history of Jewish life in Sioux City.

Schultz, Joseph P., and Carla L. Klausner. "Rabbi Simon Glazer and the Quest for Jewish Community in Kansas City, 1920-1923." American Jewish Archives 35 (April 1983), 13-26.

This essay describes a portion of the later career of Rabbi Simon Glazer, author of The Jews of Iowa (Des Moines, 1904), focusing in particular on Rabbi Glazer's involvement in the development of what he described as his "Kansas City Plan" to federate the Orthodox Jewish community. To this end Rabbi Glazer obtained state and city charters for the United Synagogues so that they operated with the sanction of the laws of both Kansas City and the state of Missouri. Using this legal sanction, Rabbi Glazer organized a free Talmud Torah supervised by the United Synagogues and obtained a separate allotment from the Allied Charities of Kansas City for the Orthodox community. He also exercised the legal right under the charters to prevent fraud and deception in the handling of meat and to certify that claims of kosher were valid.

\section{NEWSPAPER ARTICLES (OTHER THAN IOWA NEWSPAPERS)}

Chicago Tribune, 23 October 1986.

Reporting on results of a poll conducted by the Louis Harris organization on attitudes of people in Nebraska and lowa about whether Jewish international bankers are to blame for the farm crisis. A correction of the incorrectly stated results of the poll was published the next day (24 October). 
Chicago Tribune, 7 November 1992. "Kosher - In rural Iowa, residents learn the ways of their Orthodox Jewish neighbors."

Christian Science Monitor, 25 November 1985.

Joseph Rudin column on Iowa farmers involved in the Posse Comitatus.

Houston Post, 30 November 1985.

Joseph Rudin column on a 20/20 television program on the farm crisis and anti-Semitism.

Sioux City Californian. Published 1977-1983. American Jewish Archives, Hebrew Union College, Cincinnati, Ohio.

Newsletter, published annually, containing news, photographs, reminiscences, etc. of Sioux Citians who have relocated to California. Reports on the group's annual picnic, held in Los Angeles.

Wall Street Journal, 17 July 1986. "Delicate Balance: Keeping the Sabbath and a worldly career tests religious Jews; time spent away from jobs is made up; an adman keeps kosher at Ogilvy; saying no way to Ames, Iowa."

Washington Post, 24 September 1988. Nat Hentoff, "From creches to Christmas trees to a menorah in Iowa."

\section{DISSERTATIONS}

\section{Iowa}

Hinchin, Martin I. "A History of the Jews of Sioux City, Iowa, 18571945." Rabinnical degree thesis, Hebrew Union College, 1946.

Slocom, Robert Page. "Politics and Fiction: A Novel and an Essay." Ph.D. diss., University of Iowa, 1982.

\section{General Reference}

Lazar, Robert Jordan. "From Ethnic Minority to Socio-Economic Elite: A Study of the Jewish Community of Fargo, North Dakota." Ph.D. diss. University of Minnesota, 1968. 


\section{PAMPHLETS}

McQuiston, Isobel. A History of Temple Judah of Cedar Rapids. Cedar Rapids: Temple Judah, 1989.

Prepared to celebrate twenty-five years in their current building, this booklet offers a brief history of the Cedar Rapids community and its congregations. It includes information on the founding of its organizations, schools, youth groups, etc.; lists rabbis and past officers; and reprints photographs of confirmation classes from 1925 through 1988.

Moeller, Hubert L. They Came to Iowa: A Brief History of Ethnic Groups. Palmer, 1976.

This booklet, published by the author, provides brief information on ethnic groups that have settled in lowa. A single-page entry (56) mentions some early Jewish immigrants, relates some basic information on Judaism and notes that six thousand Jews live in Iowa, more than half in Des Moines, at the time of its publication.

Musin, Howard, ed. Beth El Jacob Centennial Celebration, 1885-1985. Des Moines: Beth El Jacob Synagogue, 1985.

Prepared for this Orthodox synagogue's centennial celebration, this booklet offers a brief history of the congregation, reprints early synagogue bylaws, and lists former rabbis and past presidents (with concise biographies of some). Includes many photographs and the centennial celebration program.

\section{MANUSCRIPTS}

Appel, Alexander M. Reminiscences of Andersonville Prison. 1916. American Jewish Archives, Hebrew Union College, Cincinnati, Ohio.

A privately published account of the experiences of a member of the Sixteenth Iowa Regiment in Andersonville Prison.

Centennial Historic Sketches. Newsletter of the Sioux City Jewish Federation, 1968. American Jewish Archives, Hebrew Union College, Cincinnati, Ohio.

Compilation of historical sketches prepared for the Sioux City Jewish Federation Newsletter. Relates incidents concerning pioneer families, the founding of community organizations, etc. 
Cohen, Harry A. Untitled. 1954. American Jewish Archives, Hebrew Union College, Cincinnati, Ohio.

Cohen, a member of Waterloo's Jewish community, prepared this one-page history of the community for Waterloo's 1954 centennial celebration.

"David A. Magee." Undated. American Jewish Archives, Hebrew Union College, Cincinnati, Ohio.

A brief biographical sketch of David A. Magee (1849-1927), a Sioux City resident for 58 years. A prominent businessman, he served as mayor and city alderman.

Davidson, Mary. "An Autobiography of Mary Davidson, 1869-1940." 1972. American Jewish Archives, Hebrew Union College, Cincinnati, Ohio.

A personal memoir written by Mary Davidson (born 1869 in Lithuania), whose family emigrated to Des Moines when she was 12. In 1888 she married Saul Davidson, who became a prominent Des Moines merchant. Her memoir provides a personal look at the society and culture of the period.

Eisenberg, Frederick A. "Jewish Life in Small Towns of the Midwest as Seen in The Israelite, 1854-1855." Term paper, Hebrew Union College, 1956.

This Hebrew Union College term paper looks at Jewish life in small midwestern towns through articles and advertisements published in The Israelite, a popular Jewish magazine published by Isaac $M$. Wise. The publication often noted the founding of new communities and organizations. An appendix lists the towns mentioned during the period discussed and the date on which the entries appeared. The Iowa towns listed are Columbia City, Davenport, Dubuque, Fort Madison, Keokuk, and Rushville.

Goldberg, Albert. "The Store: A Family Memoir." Unpublished manuscript, 1981. American Jewish Archives, Hebrew Union College, Cincinnati, Ohio.

Written in response to a family member's request, this manuscript tells of Sam Goldberg's emigration from Poland in the 1860 s, of his founding of a dry goods store in Shenandoah, Iowa, and of the four generations of the family who maintained the store until 1981. Contains many personal reminiscences and references to events and people of the period. 
Goldberg, Louis S. "Ordinary American: An Autobiography." Sioux City, 1977. American Jewish Archives, Hebrew Union College, Cincinnati, Ohio.

An autobiographical manuscript, written in response to a family member's request, describing the author's life as a child of Russian emigrés in the United States. Born in New York and educated in Baltimore, Mr. Goldberg came to Sioux City in 1919 and became a successful attorney there. He tells how he chose Sioux City after visiting several midwestern cities. Includes letters, his thoughts on books he has read, on religion, anti-Semitism, etc.

Levitt, Jennie D. "The Life of My Father-Saul Davidson." 1968. American Jewish Archives, Hebrew Union College, Cincinnati, Ohio.

Remarks delivered at the annual dinner of the Jewish National Fund of Minneapolis honoring Mrs. Thomas I. (Jennie) Levitt, November 24, 1968. Summarizes the life of Saul Davidson, emphasizing his contributions to the Des Moines Jewish Community.

Mannheimer, Eugene. Notebooks. American Jewish Archives, Hebrew Union College, Cincinnati, Ohio.

More than 1,700 pages of notes on the Jewish community of Des Moines in five volumes by the rabbi of Temple B'nai Jeshurun (1905-1952), Des Moines' Reform Congregation. Includes information on synagogue history, social and religious organizations, charities, social work, and the creation of the Jewish Federation of Greater Des Moines.

Shinedling, Abraham I. "Leo Mannheimer and His Family: A Memoir." Unpublished manuscript. 1959-1960. American Jewish Archives, Hebrew Union College, Cincinnati, Ohio.

A family biography of the Mannheimer family, with special reference to Rabbi Leo Mannheimer, father of Rabbi Eugene Mannheimer of Des Moines Congregation B'nai Jeshurun. Pages 192-221 cover the life of Eugene Mannheimer. Also includes a record of correspondence between the author and surviving members of the Mannheimer family.

Sutherland, O. Clyde. Section of manuscript on religious groups in Iowa. 1939. American Jewish Archives, Hebrew Union College, Cincinnati, Ohio.

Section on Judaism in Iowa from a study on religion in the state done (at least in part) as a WPA project. Correspondence 
regarding the project is included, as is a list of congregations extant in 1939.

Zober, Edith (with additions by other members of the congregation). "A Personal Account of the History of the Ames Jewish Congregation." Undated. American Jewish Archives, Hebrew Union College, Cincinnati, Ohio.

Summarizes the events leading up to the founding of the Ames Jewish Congregation. Provides an intimate, detailed view of the progression from meeting in a university room to the rental of space in a local church to the building of the current facility.

\section{PAPERS}

Baron de Hirsch Fund. Correspondence. American Jewish Historical Archives, Brandeis University, Waltham, Massachusetts.

Five file folders of uncatalogued correspondence dealing with the settlement of Jewish immigrants in Iowa (1905-1915) under the auspices of the Baron de Hirsch Fund and, particularly, through the Galveston Project, which brought new immigrants directly from Europe to the Middle Western and Far Western United States.

Davidson Bros. Inc. Business and personal papers. Sioux City Public Museum, Sioux City, Iowa.

Fifteen linear feet of uncatalogued papers dealing with the foundation and operation of Davidson Bros. department stores in Sioux City. Includes correspondence, materials relating to the daily operation of the stores, manifests, etc.

Industrial Removal Office. Correspondence. American Jewish Historical Archives, Brandeis University, Waltham, Massachusetts.

One and one-half linear feet of uncatalogued correspondence dealing with the work of the Industrial Removal Office of New York City (originally a branch of the Jewish Agricultural Society of America and after 1905 its own separate organization) in settling already-arrived immigrants in Iowa. The correspondence is divided into four parts: requests for aid to families and individuals, letters of response from the New York office, correspondence between the IRO and its Iowa agents, and letters from those settled by the IRO in the state. 
Mannheimer, Eugene. Personal Papers. American Jewish Archives, Hebrew Union College, Cincinnati, Ohio.

Seven and one-half linear feet of uncatalogued papers, correspondence, sermons, and miscellaneous materials from the rabbi of Temple B'nai Jeshurun, Des Moines' Reform congregation (1905-1952).

Temple B'nai Jeshurun. Papers. Temple B'nai Jeshurun Archives, Temple B'nai Jeshurun, Des Moines, Iowa.

Catalogued papers, synagogue records, temple board minutes, sisterhood materials, temple bulletins, notebooks, photograph albums, and miscellaneous materials. 
Copyright of Annals of Iowa is the property of State of Iowa, by \& through the State Historical Society of Iowa and its content may not be copied or emailed to multiple sites or posted to a listserv without the copyright holder's express written permission. However, users may print, download, or email articles for individual use. 